\title{
Perancangan dan Implementasi Aplikasi Keuangan Gereja Jemaat UNAI Berbasis Web Menggunakan Yii Framework
}

\author{
Andrew Fernando Pakpahan ${ }^{1}$, Valentine Siagian² dan \\ James Sylvanus Ulyreke ${ }^{2}$ \\ ${ }^{1}$ Fakultas Teknologi Informasi Universitas Advent Indonesia \\ ${ }^{2}$ Fakultas Ekonomi Universitas Advent Indonesia \\ Email: 1andrew@unai.edu, valentine@unai.edu, ulyrekejames@unai.edu
}

\begin{abstract}
Abstrak
Gereja UNAI memiliki anggota yang cukup banyak dan mempunyai transaksi keuangan yang mempunyai jumlah yang cukup besar. Sebelum penelitian ini dilakukan pencatatan transaksi keuangan masih dilakukan dengan menggunakan aplikasi yang berbeda untuk penerimaan dan pengeluaran sehingga membutuhkan proses yang tidak singkat untuk membuat laporan keuangan akhir. Pada penelitian ini dirancang suatu aplikasi keuangan gereja yang memungkinkan pencatatan penerimaan dan pengeluaran di dalam satu aplikasi yang mudah digunakan. Aplikasi dirancang dengan menggunakan metode prototyping di mana prototype aplikasi dapat langsung diimplementasikan dan diperbaharui sesuai dengan perkembangan kebutuhan dari pengguna. Aplikasi keuangan ini menyediakan fungsi pencatatan anggota, departemen, tahun anggaran, anggaran, penerimaan, pengeluaran, cash advance dan berbagai fungsi laporan seperti: laporan anggota, laporan departemen, laporan penerimaan harian, laporan penerimaan bulanan, laporan pengeluaran, laporan anggaran, laporan gabungan penerimaan dan pengeluaran.
\end{abstract}

Kata Kunci: Sistem keuangan, Aplikasi Keuangan Gereja, Aplikasi Web, Yii Framework

\section{Design and Implementation of Web-based Financial Application of UNAI Church Using Yii Framework}

\begin{abstract}
UNAI church has many members and large amount of financial activities. Before this research is done the financial transactions were recorded with different applications between income and expense. Thus requiring a long process to crate the final financial statement. In this research, a financial application that combines the income and expense recording in an easy-to-use application is designed and implemented. This application is designed with prototyping method, where an application prototype can be implemented and revised as user's demands. This financial application provides membership recording, departement management, budget year management, budgeting, income recording, expense recording, cash advance management and provides several reporting such as: membership report, departement report, daily income report, monthly income report, expense report, budget report and income and expense combined report.
\end{abstract}

Keywords: Financial application, Church Financial Application, Web Application, Yii Framework

\section{Pendahuluan}

Gereja Masehi Advent Hari Ketujuh (GMAHK) jemaat Universitas Advent Indonesia (UNAI) adalah jemaat dari gereja yang berada di dalam kampus UNAI, Bandung, Jawa Barat. Jemaat ini sedikit berbeda dengan kebanyakan jemaat GMAHK pada umumnya karena jemaat ini ada karena kebutuhan dari lembaga UNAI untuk menyelenggarakan kebaktian yang diikuti oleh staf, dosen dan juga mahasiswa. Jemaat UNAI mempunyai dua tempat perbaktian yang digunakan secara rutin yaitu: (1) Gedung Chapel, yang dapat menampung sekitar 2500 orang dan juga Gedung NDG yang dapat menampung sekitar 600 orang. Pada 
setiap minggunya ada beberapa jenis perbaktian yang dilakukan yaitu: Perbaktian Rabu malam, Vesper (diadakan setiap Jumat malam), Sekolah Sabat, Khotbah dan Pemuda Advent yang diadakan setiap hari Sabtu. Dalam mendukung pelayanan jemaat, anggota jemaat UNAI setiap tahunnya memilih pengurus jemaat UNAI, yang dibagi ke dalam 22 departemen dengan tanggung jawab yang spesifik untuk masingmasing bidang.

Untuk mendukung operasional sehari-hari jemaat UNAI mempunyai beberapa sumber pendapatan, di antaranya adalah Perpuluhan, Persembahan dan penerimaan lainnya. Jenis penerimaan yang merupakan salah satu doktrin GMAHK yang mengajarkan tentang perpuluhan, di mana setiap anggota diwajibkan untuk membawa sepersepuluh dari pendapatannya kepada gereja. Hal ini dilakukan sebagai bentuk iman, kepercayaan kepada Tuhan bahwa Tuhan akan mencukupkan bagian dari pendapatan yang digunakan anggota dalam kehidupan sehari-hari. Di dalam 28 doktrin gereja Advent yang dikutip dari situs resmi GMAHK sedunia [1] yang diterjemahkan sebagai berikut "Kita adalah para penatalayanan Allah, yang Dia percayakan dengan waktu dan kesempatan, kesanggupan dan harta, dan berkat-berkat bumi, serta segala sumber dayanya. Kita bertanggung jawab kepada Dia dalam penggunaan hal-hal tersebut secara tepat. Kita mengakui kepemilikan Allah melalui pelayanan yang setia kepada-Nya dan sesama, serta mengembalikan persepuluhan dan memberikan persembahan bagi pengabaran Injil-Nya dan sokongan serta perkembangan gereja-Nya". Perpuluhan biasanya dikumpulkan pada kebaktian Sabat pertama setelah tanggal 25. Selain dari persepuluhan jemaat UNAI juga mendapatkan pendapatan melalui persembahan yang diberikan oleh jemaat pada kebaktian. Ada beberapa jenis persembahan yang dikumpulkan yaitu: persembahan sekolah sabat, persembahan khotbah, persembahan khusus jemaat, persembahan khusus beasiswa dan persembahan pemuda Advent. Jenis pendapatan yang terakhir adalah pendapatan lainnya yang merupakan pendapatan yang didapatkan selain perpuluhan dan persembahan yang telah disebutkan sebelumnya. Pendapatan jenis ini dapat berupa bunga bank ataupun dana yang diberikan oleh kantor pusat GMAHK UNAI untuk daerah Jawa Barat yaitu Konferens Jawa Barat (KJB). Dari dana yang terkumpul dari jemaat, uang perpuluhan akan dikirim sepenuhnya ke Konferens Jawa barat sedangkan persembahan selain persembahan khusus jemaat dan persembahan khusus beasiswa akan dibagi menjadi dua bagian: $50 \%$ akan dikirim ke KJB dan 50\% akan menjadi pendapatan jemaat.

Dalam melayani anggota jemaat, pengurus jemaat UNAI harus menggunakan dana yang telah terkumpul dengan sebaik mungkin. Untuk itu di awal tahun pelayanan, majelis jemaat akan berkumpul untuk menentukan anggaran pengeluaran untuk setiap departemen. Setelah anggaran departemen ini disetujui oleh majelis jemaat, maka anggaran ini akan menjadi acuan bagi masing-masing ketua departemen untuk menjalankan program di departemen yang dipimpinnya. Untuk melaksanakan program kerja biasanya ketua departemen akan melakukan Cash advance yaitu meminta uang kepada Bendahara jemaat untuk dapat digunakan untuk melakukan acara yang diprogramkan. Setelah program telah selesai dilakukan maka ketua departemen tersebut akan melaporkan rincian pengeluaran kepada Bendahara yang akan dicatat oleh Bendahara jemaat sebagai pengeluaran untuk departemen tersebut. Dalam periode waktu tertentu majelis jemaat akan berkumpul untuk memperoleh informasi tentang keuangan jemaat dari Bendahara yang akan menginformasikan tentang jumlah penerimaan dan juga pengeluaran dari jemaat UNAI.

Bendahara jemaat mempunyai peran inti dalam melakukan pencatatan penerimaan, pengeluaran dan pelaporan keuangan jemaat. Pada sabat perpuluhan, anggota jemaat akan memberikan perpuluhan dan persembahan ke dalam amplop khusus yang dimasukkan ke dalam kotak perpuluhan pada waktu yang khusus di dalam kebaktian. Kemudian, kotak perpuluhan ini dibuka oleh Bendahara jemaat dan amplopamplop yang ada akan dibuka dan uang di dalamnya akan dihitung ulang, apakah sudah sesuai dengan angka yang dituliskan di masing-masing amplopnya. Setelah itu Bendahara harus mencatat setiap pemberi dan nominal pemberiannya. Kemudian, kwitansi penerimaan harus dipersiapkan dan dimasukkan kembali ke dalam amplop perpuluhan yang akan dikembalikan kepada si pemberi.

Sebelum penelitian ini dilakukan Bendahara jemaat menggunakan aplikasi pencatatan penerimaan keuangan jemaat yang tidak dapat diandalkan, di mana aplikasi yang digunakan sering bermasalah dan pencatatan yang dilakukan tidak dapat dilakukan dengan optimal, selain itu aplikasi yang ada tidak dapat 
mencatat anggaran, cash advance, pengeluaran dan tidak dapat membuat laporan gabungan penerimaan dan pengeluaran jemaat. Oleh karena itu penelitian ini dilakukan di mana di dalam penelitian ini dirancang suatu aplikasi keuangan jemaat UNAI yang dapat membantu Bendahara jemaat dalam melakukan pekerjaannya sehingga dapat melakukan pencatatan transaksi keuangan dengan akurat dengan aplikasi yang mudah digunakan dan dapat menghasilkan laporan keuangan yang dituntut oleh majelis jemaat. Laporan keuangan ini nantinya akan dilaporkan pada konferensi jemaat yang menunjukkan jumlah persepuluhan yang diterima dan dikirimkan kepada bendahara Konferens dan juga pengumuman tentang keadaan keuangan jemaat berapa yang diterima dan yang telah digunakan [2].

\section{Metode Penelitian}

Bagian ini akan memperlihatkan dan menjelaskan tentang arsitektur dan metodologi penelitian yang digunakan dalam bentuk gambaran konseptual dari aplikasi yang dikembangkan. Pada Gambar 1 dapat dilihat arsitektur aplikasi keuangan gereja yang dikembangkan dimana Bendahara menggunakan perangkat komputer untuk mengakses aplikasi keuangan gereja berbasis web yang dijalankan di Web Application Server dan terhubung dengan tempat penyimpanan data di Database Server. Aplikasi yang dikembangkan menggunakan bahasa pemrograman PHP dengan menggunakan Yii Framework yang adalah framework PHP yang menekankan pada high performance, component-based PHP untuk mengembangkan aplikasi web yang modern [3]. Dengan menggunakan Yii, aplikasi dapat dikembangkan dengan lebih cepat dengan menggunakan arsitektur MVC (Model-View-Controller) yang dapat mengorganisasikan kode berdasarkan fungsi dan tujuannya. Sehingga dalam mengembangkan aplikasi, kode yang ada dapat terstruktur dengan baik dan mudah dimengerti.

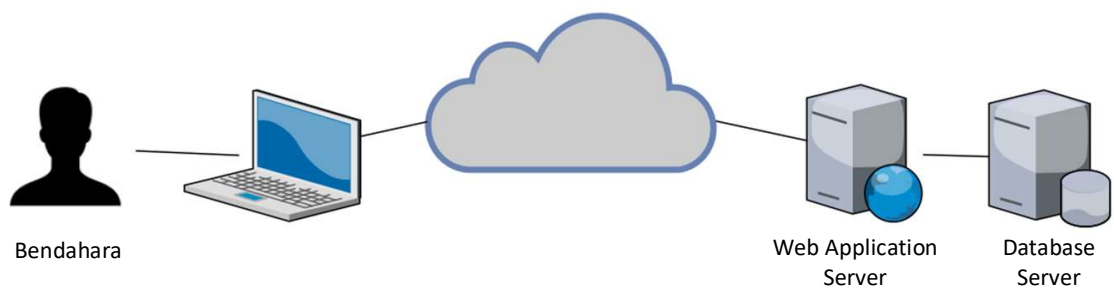

Gambar 1 Arsitektur Aplikasi Keuangan Gereja UNAI

Model pengembangan Prototyping (Gambar 2) disarankan untuk dapat mengembangkan sebuah aplikasi secara cepat dan menghasilkan suatu produk yang dapat langsung digunakan dan dievaluasi untuk dapat dikembangkan lebih lanjut. Bagi pengguna yang tidak terbiasa dengan tahap-tahap pengembangan sistem, penggunaan model ini memungkinkan sebuah aplikasi untuk dapat dicoba secara cepat dengan komunikasi sederhana dan kemudian dapat dikembangkan secara bertahap atau digunakan sebagai tahap awal dalam metode pengembangan lainnya [4]. 


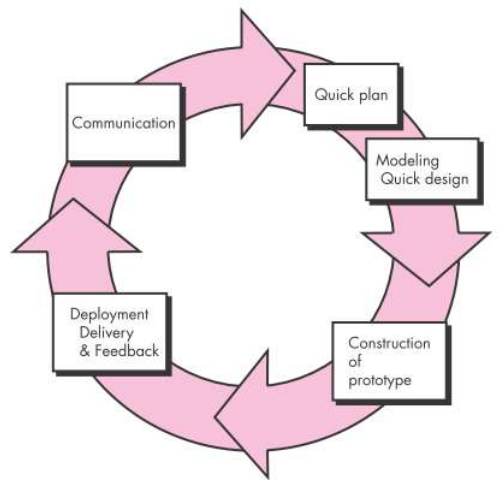

Gambar 2 Model pengembangan prototyping [5].

\section{Penelitian Terdahulu}

Penulis dalam [5] melakukan penelitian untuk merancang sistem informasi keuangan gereja berbasis PHP dan MySQL untuk gereja GMIM Bukit Moria di Manado. Sistem yang dikembangkan dapat mempercepat pengolahan data dan pembuatan laporan sehingga informasi yang dihasilkan lebih akurat, cepat lengkap dan memperkecil kesalahan.

Penulis dalam [6] melakukan penelitian dalam penerapan sistem informasi akuntansi penerimaan dan pengeluaran kas untuk perencanaan dan pengendalian internal jemaat GMIM Nafiri Malayang Satu. Penelitian tersebut menyimpulkan bahwa sistem informasi akuntansi dapat membuat keputusan dalam aktivitas perencanaan dan menyediakan pengendalian internal yang memadai, termasuk pengendalian keuangan.

Pada penelitian-penelitian terdahulu aplikasi atau sistem informasi keuangan yang dikembangkan tidak dapat diimplementasikan di gereja UNAI karena mempunyai sistem pencatatan keuangan yang berbeda. Dengan demikian untuk dapat memenuhi kebutuhan pencatatan dan pelaporan keuangan di gereja UNAI dibutuhkan perancangan suatu aplikasi keuangan yang dapat memenuhi alur proses keuangan yang ada dan dapat diimplementasikan secara langsung di gereja UNAI.

\section{Analisis Sistem}

Bagian ini memuat analisa dari sistem yang dikembangkan dalam bentuk Use Case Diagram Unified Modeling Language (UML) yang ditunjukkan pada Gambar 3 dan database relationship diagram yang ditunjukkan pada Gambar 4. Pada Use Case Diagram yang ditunjukkan, Bendahara adalah aktor tunggal yang menggunakan aplikasi. Aplikasi yang dikembangkan mempunyai use case sebagai berikut: atur penerimaan, atur anggota, atur anggaran, atur tahun anggaran, atur departemen, atur pengeluaran, atur cash advance. Atur penerimaan digunakan untuk mencatat penerimaan dari anggota jemaat. Atur anggota digunakan untuk mencatat data anggota jemaat. Atur anggaran digunakan untuk mencatat anggaran pengeluaran tahunan dari masing-masing departemen. Atur tahun anggaran digunakan untuk mencatat tahun anggaran yang digunakan, tahun anggaran aktif dan saldo awal. Atur departemen digunakan untuk mendefinisikan departemen-departemen yang ada di jemaat. Atur pengeluaran digunakan untuk mencatat pengeluaran per departemen. Atur cash advance digunakan untuk mencatat cash advance dari masingmasing departemen. Kemudian dari use case yang telah disebutkan dapat diperoleh kemampuan untuk use case cetak kwitansi, laporan penerimaan, laporan anggaran, laporan pengeluaran, laporan pengeluaran, dan laporan gabungan penerimaan dan pengeluaran. 


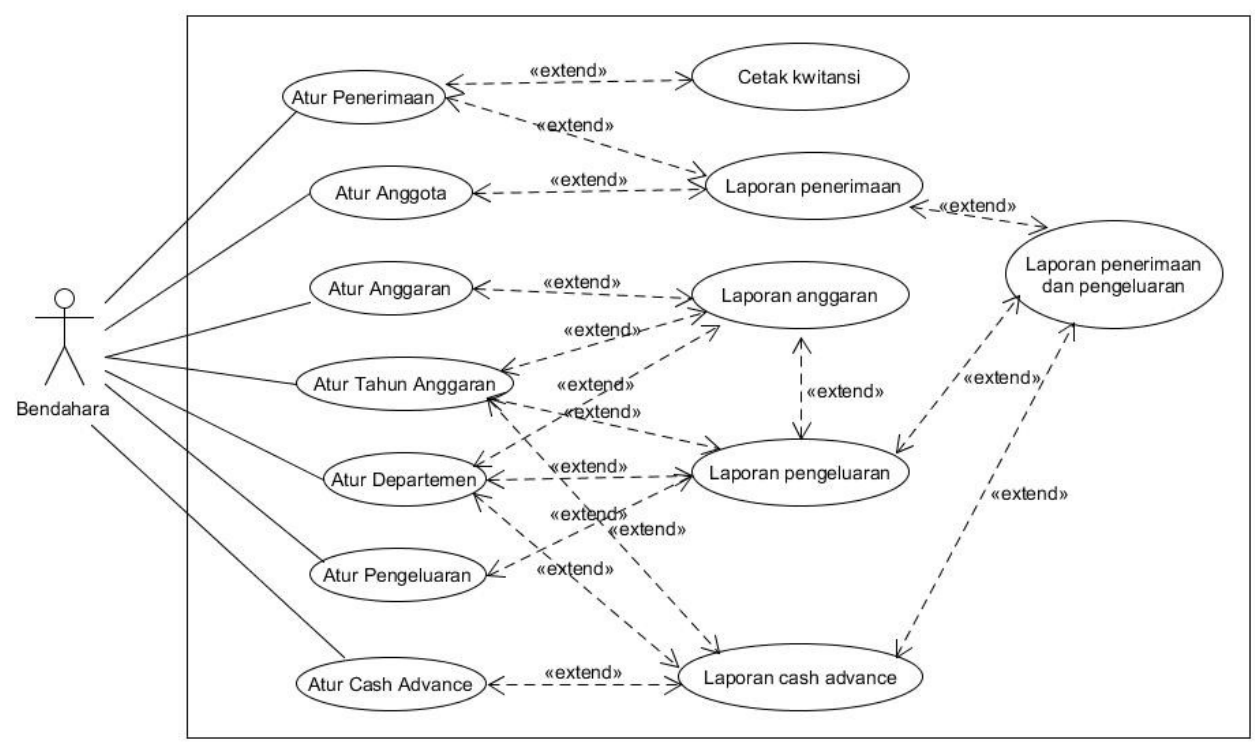

Gambar 3 Use Case Diagram dari Aplikasi Keuangan Gereja

Gambar 4 menunjukkan tabel-tabel yang digunakan dalam database untuk aplikasi yang dirancang. Ada delapan tabel yang digunakan: Anggaran, User, Pengeluaran, Departemen, tahunAnggaran, Penerimaan, Anggota, cashAdvance. Tabel anggaran menyimpan rancangan anggaran per departemen. Tabel User menyimpan data pengguna yang bisa login ke aplikasi. Tabel Pengeluaran mencatat pengeluaran per departemen. Tabel Departemen menyimpan data departemen yang ada. Tabel Penerimaan mencatat penerimaan jemaat. Tabel anggota menyimpan data anggota jemaat. Tabel CashAdvance mencatat cash advance yang dilakukan per departemen.

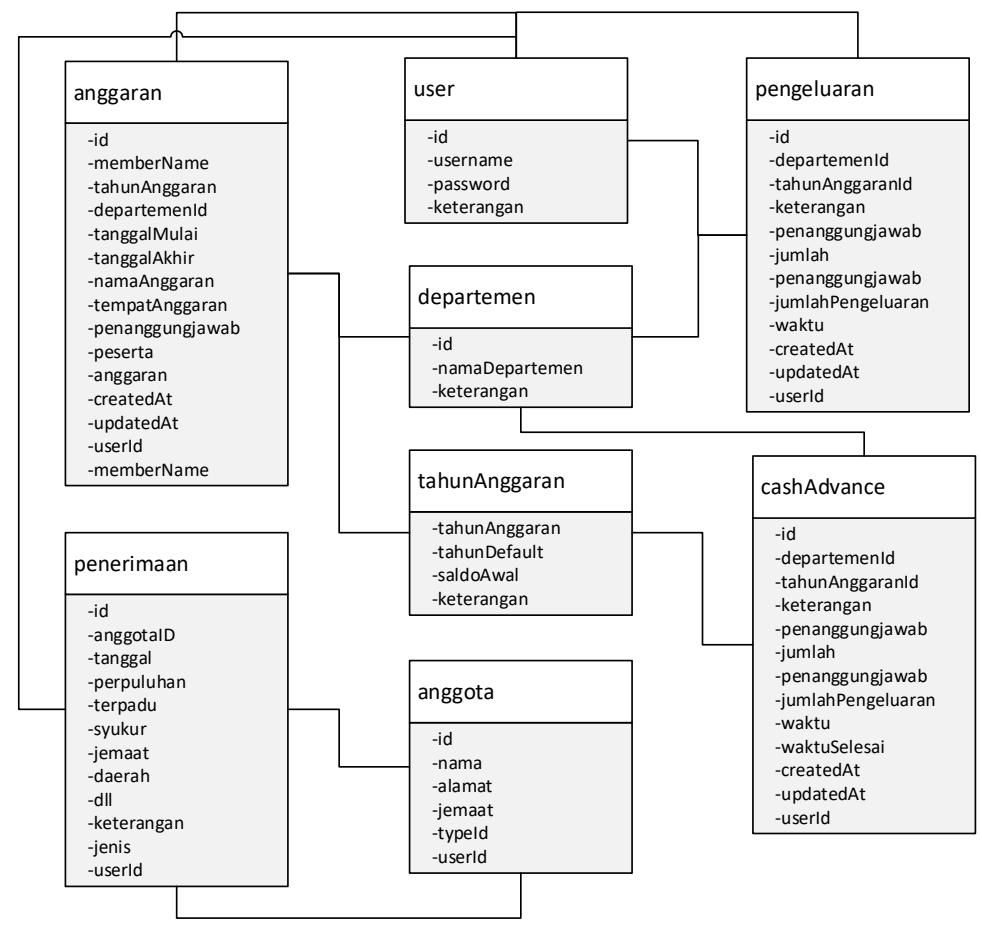

Gambar 4 Database Diagram Aplikasi Keuangan Gereja 


\section{Hasil dan Pembahasan}

Dalam bagian ini membahas mengenai hasil perancangan aplikasi dan juga bagaimana implementasi aplikasi dilakukan.

\section{Tampilan Awal}

Untuk dapat menggunakan aplikasi yang dibuat, Bendahara jemaat dapat menggunakan browser untuk mengakses alamat aplikasi yang telah ditetapkan. Setelah Bendahara melakukan login dengan username dan password yang telah ditentukan, maka tampilan Home aplikasi akan tampak seperti terlihat di Gambar 5 di bawah. Bendahara dapat mengakses berbagai fungsi aplikasi dengan meng-klik menu yang ada di sebelah atas halaman atau tombol-tombol yang tersedia di bagian bawah halaman.

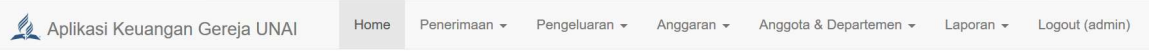

\section{Selamat Datang}

Aplikasi Keuangan Gereja UNAI

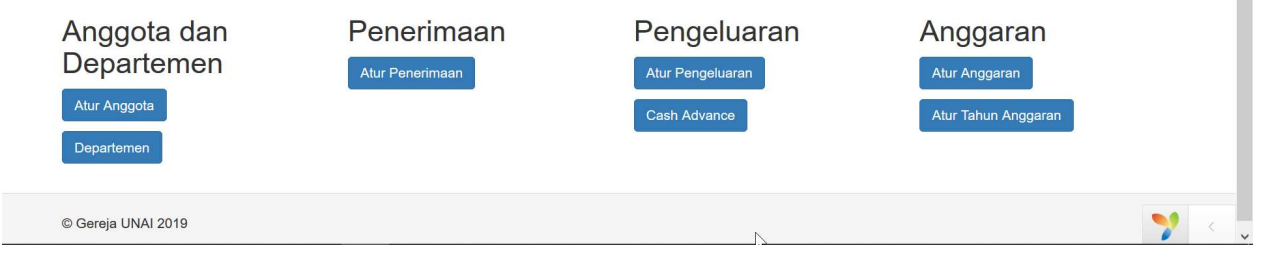

Gambar 5 Tampilan awal dari Aplikasi Keuangan Gereja UNAI

\section{Tampilan Anggota}

Untuk dapat menggunakan aplikasi, Bendahara dapat memulai dengan mencatat informasi anggota jemaat dengan mengakses fungsi Atur Anggota yang akan menampilkan daftar anggota yang tercatat di di dalam aplikasi (Gambar 6). Untuk membuat anggota baru Bendahara dapat meng-klik tombol Buat Anggota dan mengisikan informasi yang diminta (Gambar 7).

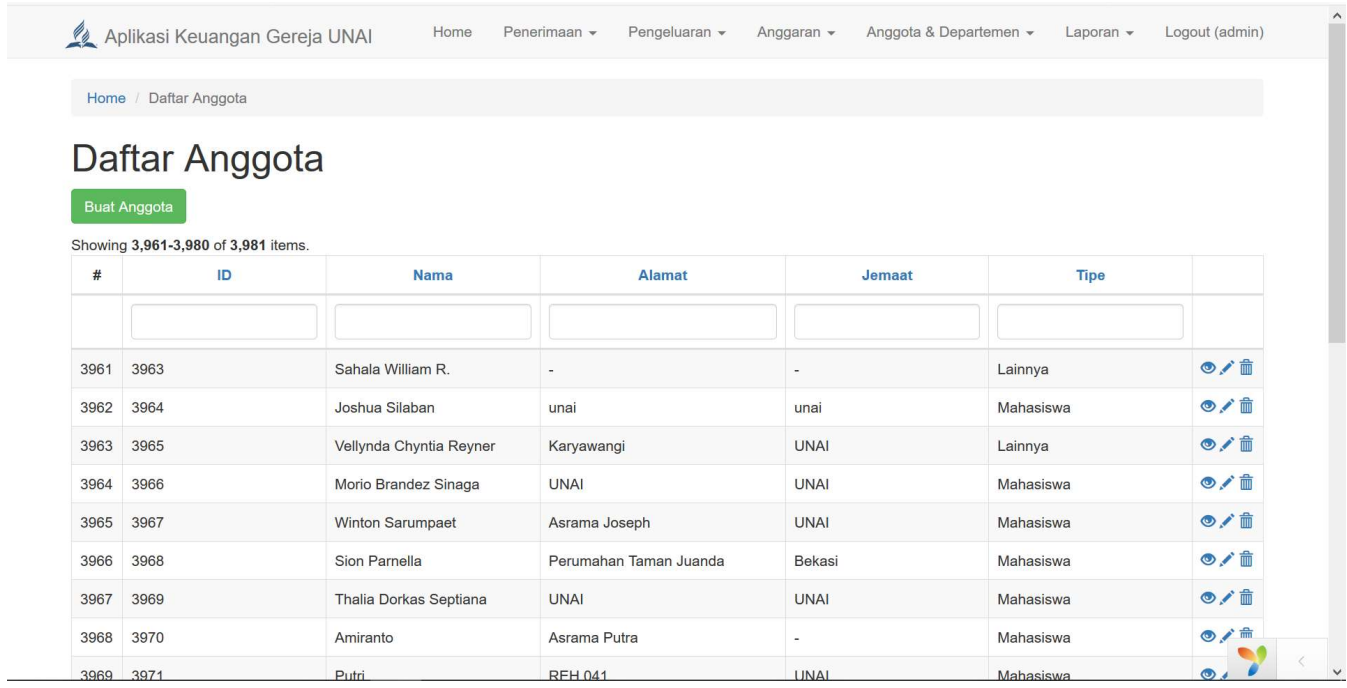

Gambar 6 Tampilan Daftar Anggota 


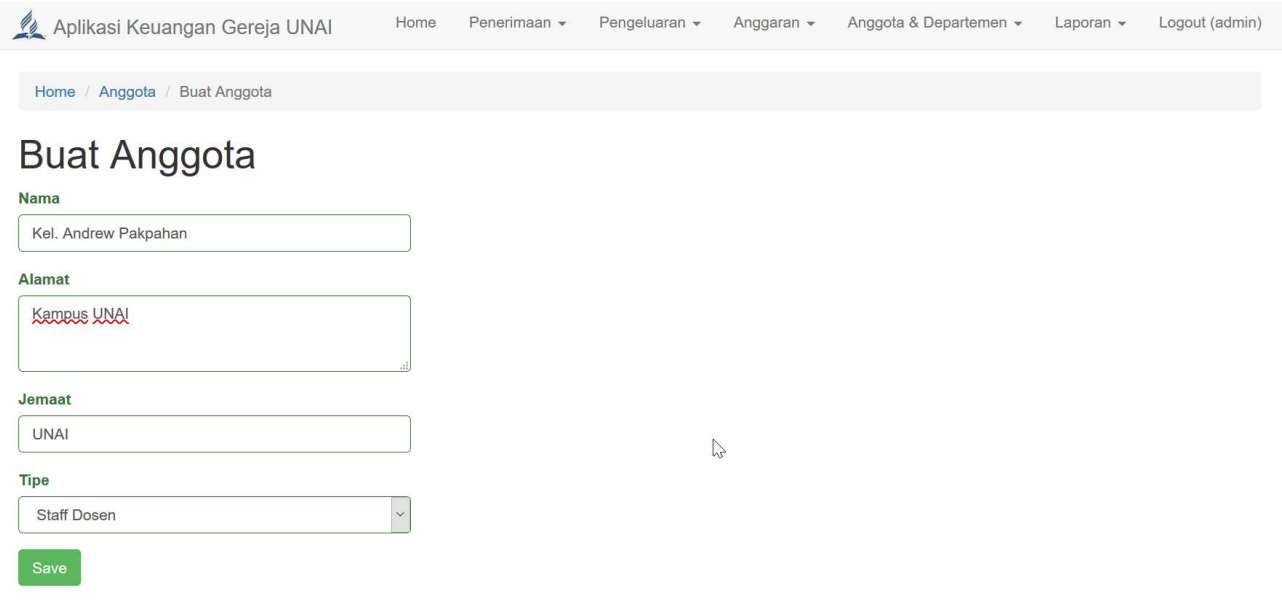

() Gereja UNAI 2019

Gambar 7 Tampilan Form untuk Buat Anggota Baru

\section{Tampilan Departemen}

Data departemen harus dibuat terlebih dahulu agar fungsi anggaran, pengeluaran, cash advance dapat berjalan dengan baik. Bendahara dapat mengklik tombol Atur Departemen dan akan dapat melihat daftar departemen yang telah ada di dalam aplikasi (Gambar 8) dan dapat meng-klik tombol Buat Departemen untuk membuat Departemen yang baru.

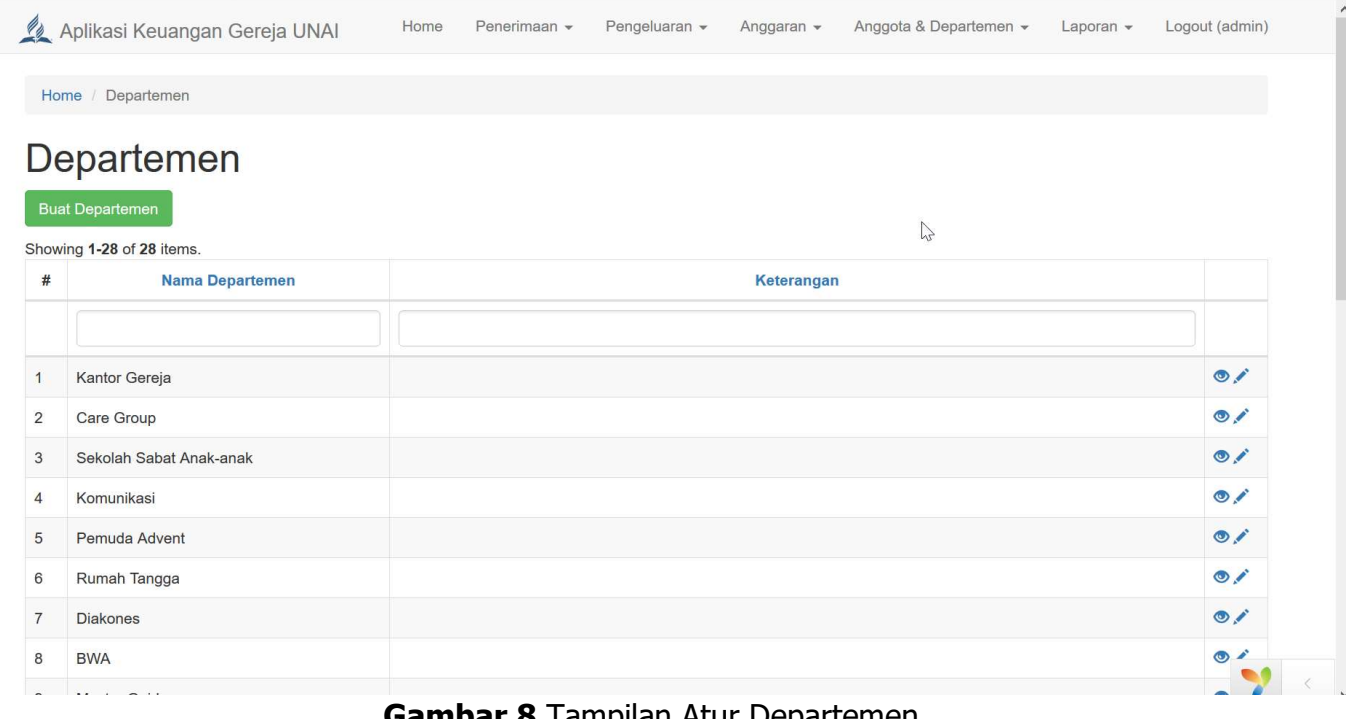

Gambar 8 Tampilan Atur Departemen

\section{Tampilan Penerimaan}

Untuk dapat mencatat penerimaan jemaat baik melalui perpuluhan dan persembahan dapat dilakukan dengan mengakses menu Penerimaan dan mengklik Input Penerimaan. Tampilan form penerimaan akan muncul seperti terlihat di Gambar 9. Aplikasi akan secara otomatis memilih tanggal sesuai hari pada saat Bendahara mengakses aplikasi untuk memudahkan penggunaan aplikasi. Kemudian Bendahara harus memilih nama anggota jemaat yang memberikan dan mengisikan nominal untuk perpuluhan, persembahan terpadu, daerah, jemaat, syukur, dll (dan lain-lain), keterangan dan jenis penerimaan (cash atau Bank). Untuk meyakinkan Bendahara bahwa data yang diisikan sudah benar, maka aplikasi akan menampilkan jumlah pemberian yang akan diperbaharui secara otomatis sesuai dengan masukan angka pada tempat 
input untuk perpuluhan dan persembahan. Setelah data yang dimasukkan sudah benar, maka Bendahara dapat mengklik tombol Simpan untuk menyimpan data. Setelah itu aplikasi akan menampilkan konfirmasi bahwa data telah disimpan dan menampilkan nomor kwitansi yang dapat dituliskan pada amplop pemberi yang dapat digunakan juga untuk mencocokkannya nanti dengan angka yang dicetak pada kwitansi.

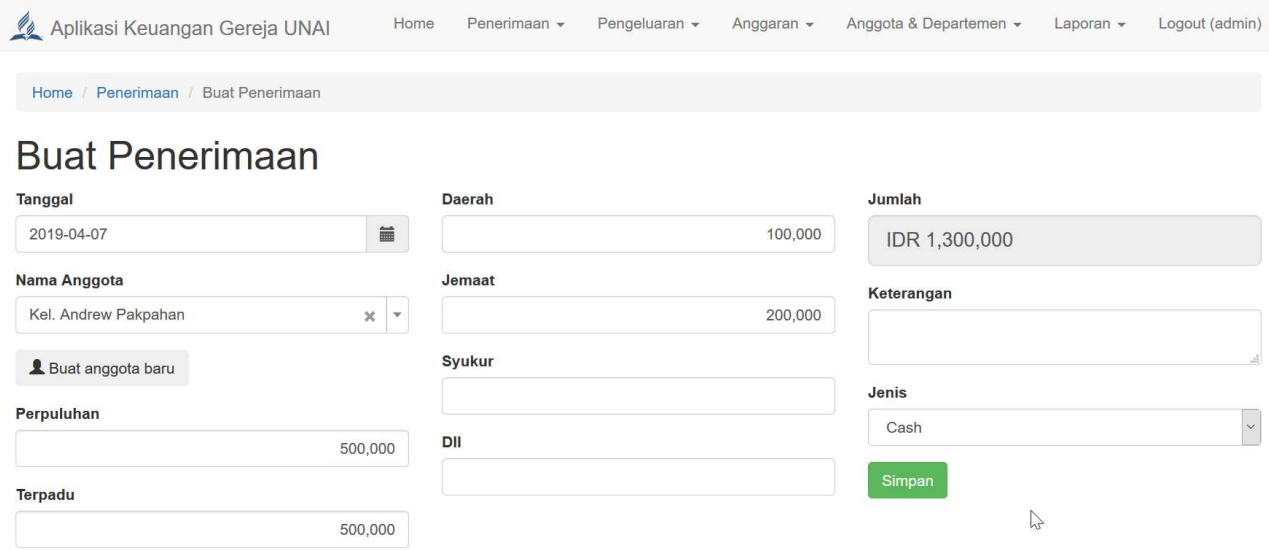

๑) Gereja UNAI 2019

Gambar 9 Tampilan Buat Penerimaan dari Aplikasi Keuangan Gereja UNAI

\section{Tampilan Tahun Anggaran}

Untuk mempermudah administrasi dan pelaporan keuangan gereja, tahun anggaran diperlukan untuk menampilkan informasi tahun anggaran yang sedang berjalan dan juga saldo awal yang dipunyai gereja pada awal tahun anggaran berjalan (Gambar 10). Hal ini diperlukan karena bisa saja Bendahara jemaat akan berganti pada saat pemilihan pegawai jemaat yang baru dan kemudian jumlah uang gereja yang diterima oleh Bendahara yang baru akan dimasukkan sebagai sebagai saldo awal di tahun anggaran yang baru. Data tahun anggaran dapat diakses melalui menu Anggaran dan kemudian meng-klik Atur Tahun Anggaran.

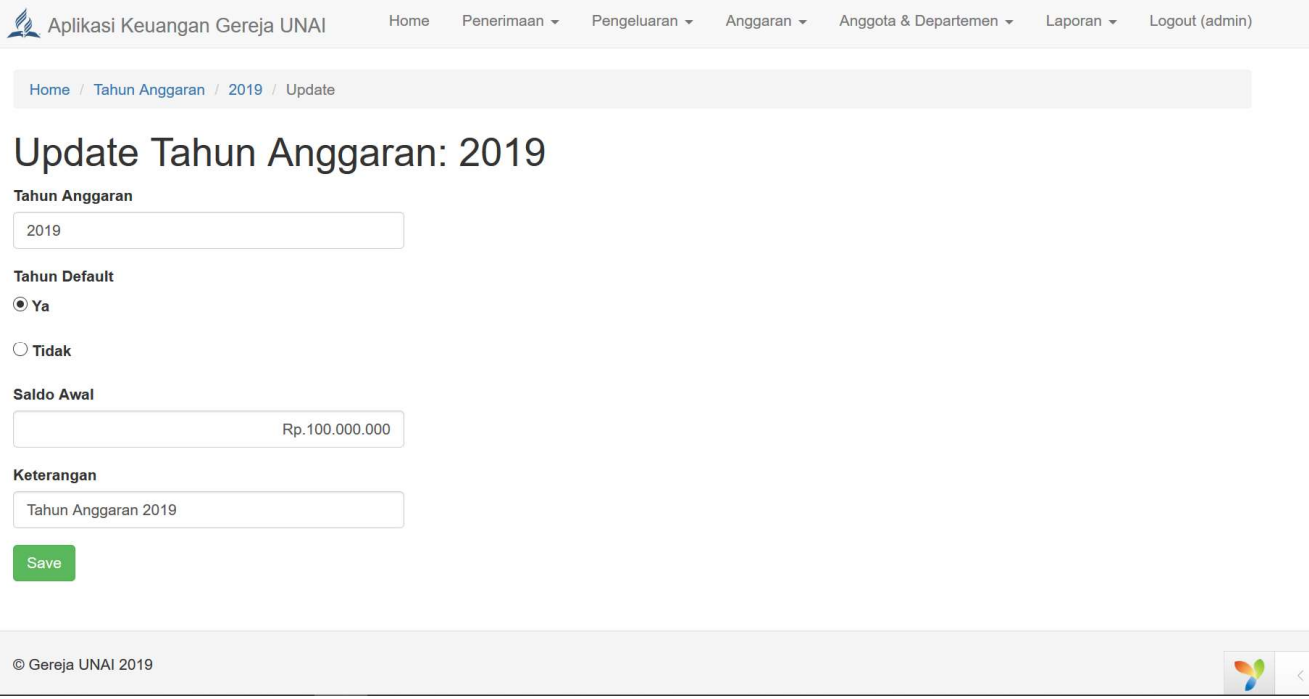

Gambar 10 Tampilan Form Tahun Anggaran 


\section{Tampilan Anggaran}

Anggaran pengeluaran jemaat dapat dimasukkan ke dalam aplikasi untuk dapat mempermudah kontrol dan pelaporan keuangan gereja. Tampilan Atur anggaran dapat dilihat di Gambar 11 ini dan tampilan form untuk memasukkan informasi anggaran dapat dilihat di Gambar 12. Pada saat anggaran dimasukkan, Bendahara harus memilih Departemen, tanggal mulai dan akhir kegiatan, tempat anggaran, peserta, dan juga nominal anggaran. Aplikasi dirancang untuk dapat memuat lebih dari satu masukan anggaran untuk setiap departemennya, walaupun pada implementasinya berdasarkan keputusan majelis jemaat anggaran yang dibuat hanya ada satu anggaran total yang dimasukkan ke Aplikasi untuk setiap tahun anggarannya.

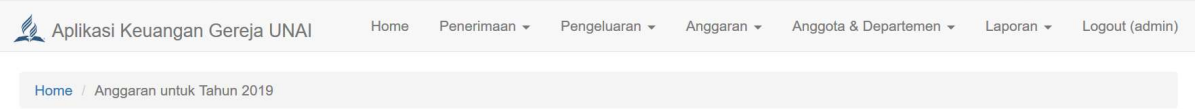

Anggaran untuk Tahun 2019

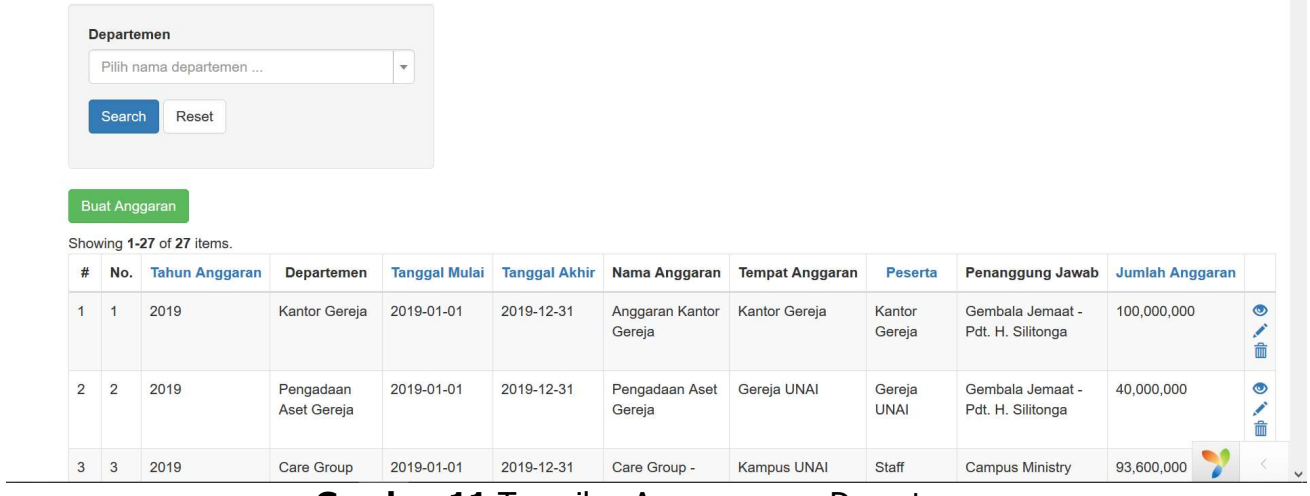

Gambar 11 Tampilan Anggaran per Departemen

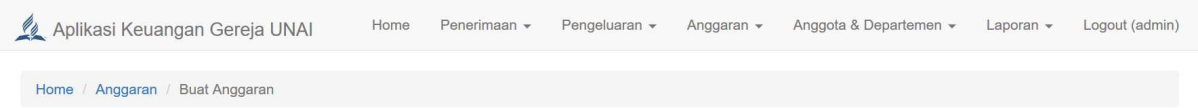

\section{Buat Anggaran}

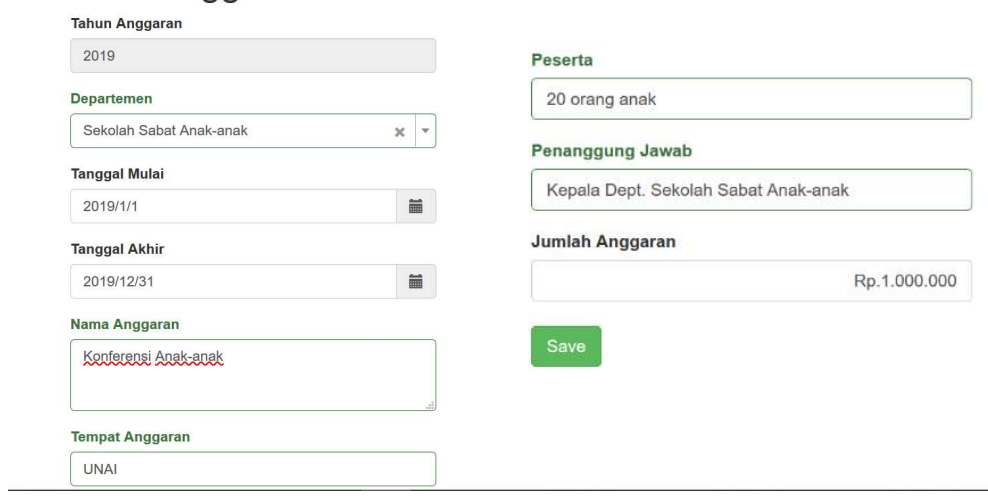

Gambar 12 Tampilan Form Buat Anggaran

\section{Tampilan Pengeluaran}

Pengeluaran jemaat dapat dicatat dengan meng-klik menu Pengeluaran dan Input Pengeluaran sehingga akan tampak tampilan Atur Pengeluaran seperti di Gambar 13. Untuk dapat mencatat pengeluaran baru, Bendahara dapat meng-klik tombol Buat Pengeluaran dan kemudian akan dihadapkan kepada form pengeluaran seperti di Gambar 14. Bendahara harus memilih Departemen yang bertanggung jawab 
terhadap pengeluaran tersebut dan kemudian mengisi nama pengeluaran, penanggungjawab dan jumlah pengeluaran.

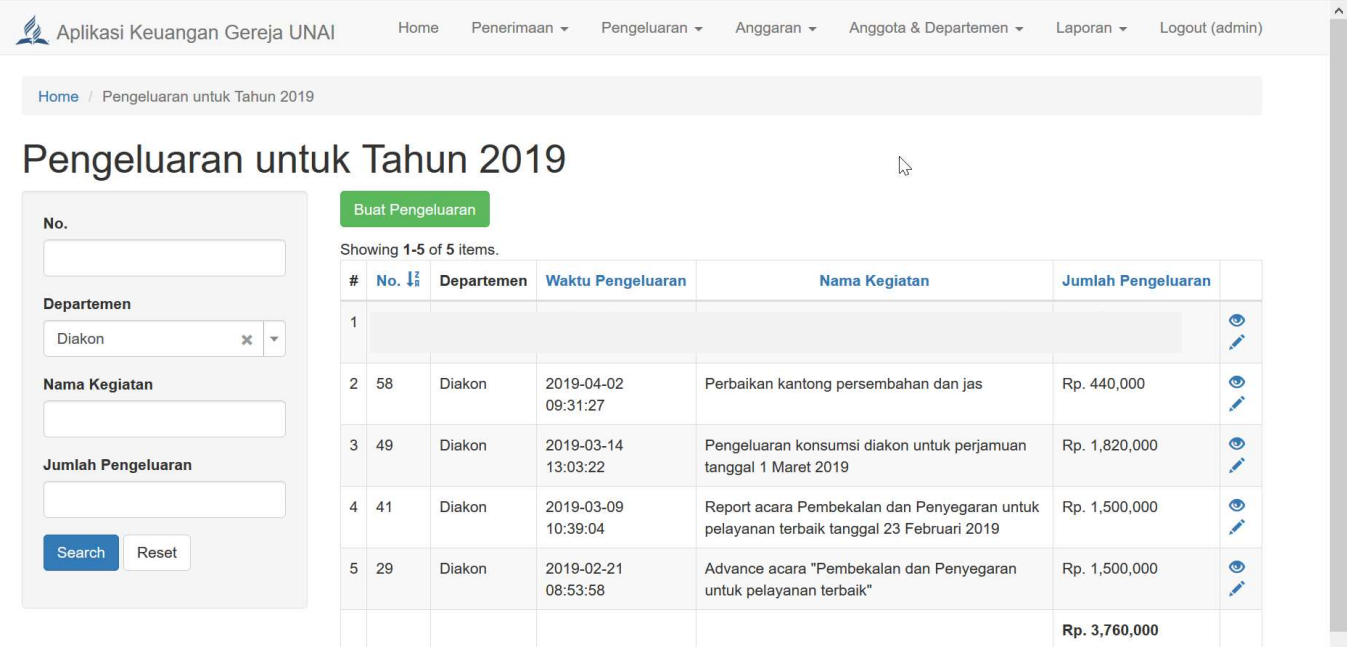

Gambar 13 Tampilan Atur Pengeluaran

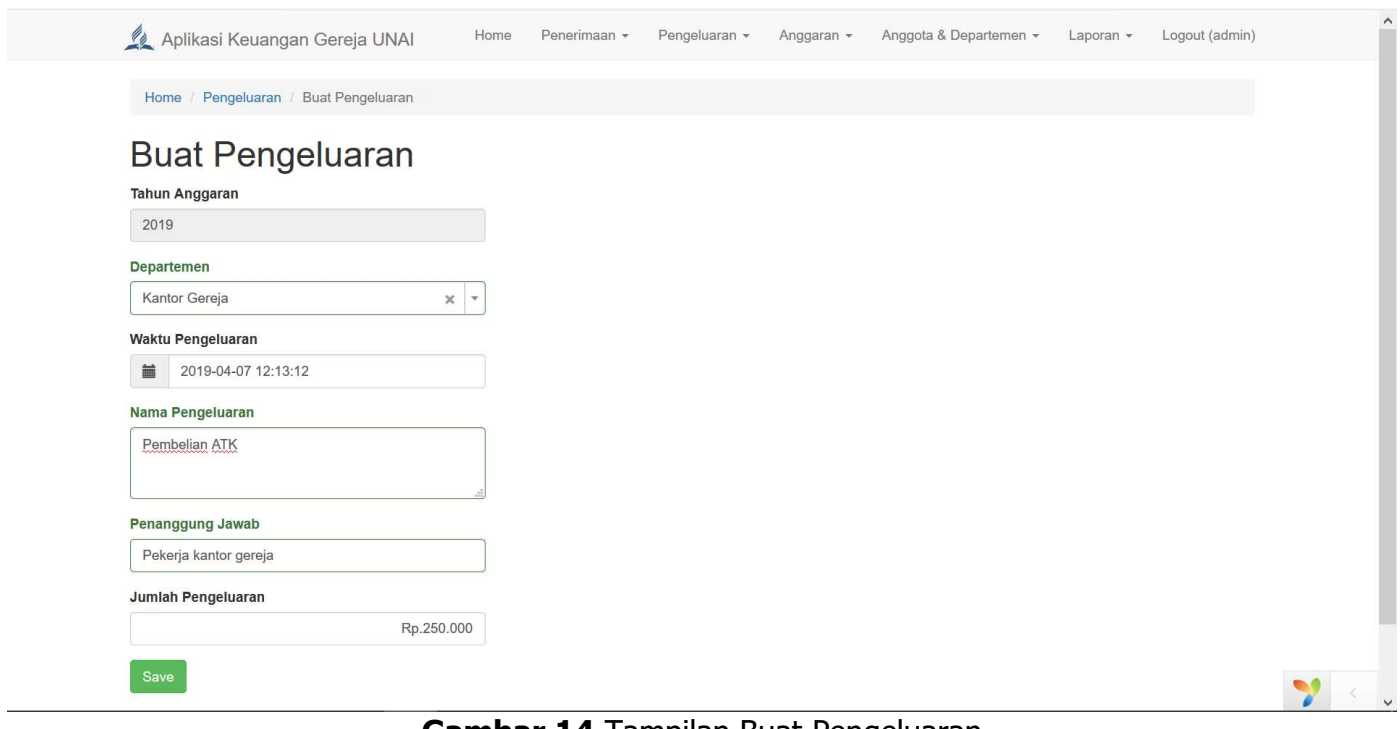

Gambar 14 Tampilan Buat Pengeluaran

\section{Tampilan Cash Advance}

Fungsi Cash advance diakses di dalam menu Pengeluaran dan kemudian Atur Cash advance sehingga akan muncul tampilan seperti di Gambar 15. Untuk dapat membuat catatan Cash advance baru, Bendahara dapat meng-klik tombol Buat Cash advance dan akan dihadapkan pada tampilan form yang hampir serupa dengan form pengeluaran, hanya yang membedakan akan ada pilihan apakah Cash advance ini sudah selesai atau tidak. Apabila status catatan Cash advance sudah selesai maka catatan Cash advance ini tidak akan tampak pada tampilan laporan keuangan gabungan. 


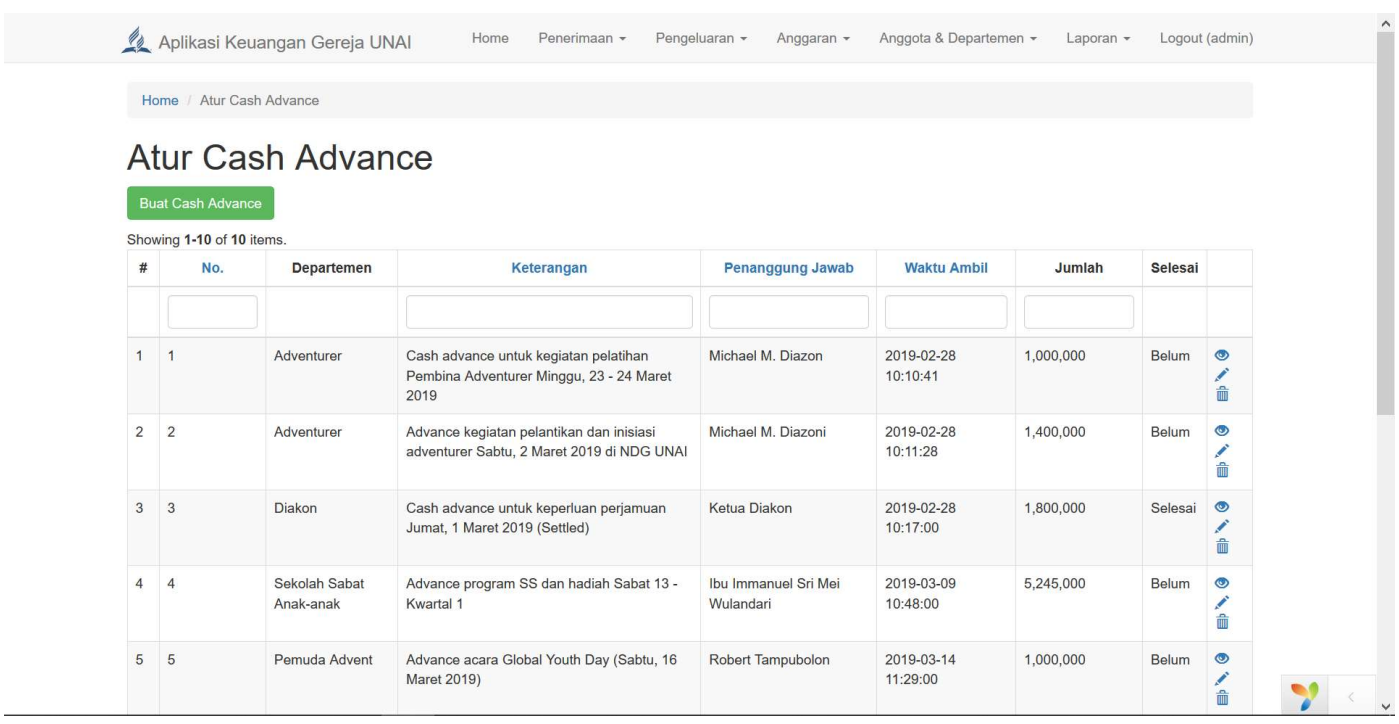

Gambar 15 Tampilan Atur Cash Advance

\section{Tampilan Print Kwitansi}

Pada saat pencatatan penerimaan sudah dilakukan Bendahara jemaat dapat melakukan print kwitansi yang akan dimasukkan ke dalam amplop perpuluhan. Ada dua pilihan untuk melakukan print kwitansi yaitu berdasarkan harian dan satuan. Print kwitansi harian (Gambar 16) memungkinkan Bendahara jemaat untuk mem-print semua kwitansi berdasarkan catatan penerimaan per hari, sedangkan print kwitansi satuan Bendahara harus memasukkan nomor kwitansi tertentu yang ingin untuk dicetak.

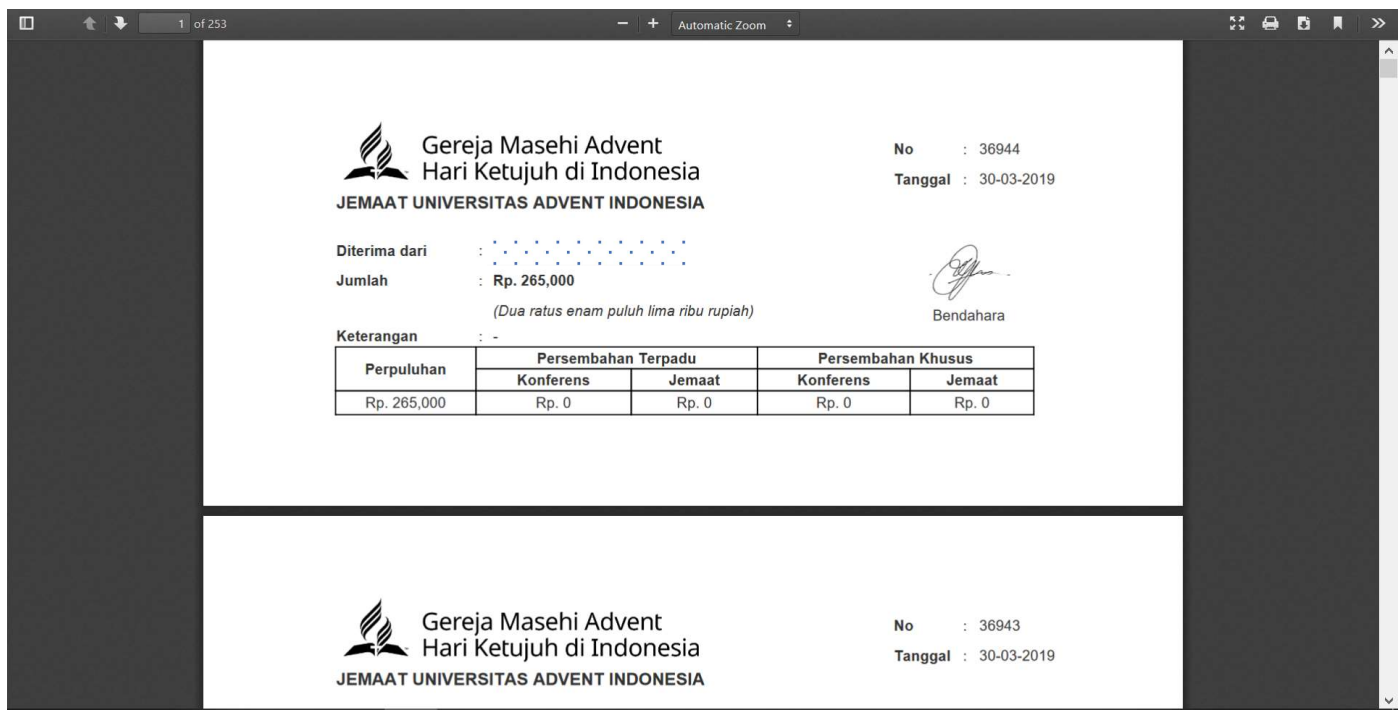

Gambar 16 Tampilan Print Kwitansi

\section{Tampilan Laporan Harian dan Bulanan}

Fungsi berikutnya yang dapat digunakan adalah Bendahara adalah laporan penerimaan harian dan bulanan di mana Laporan harian akan menampilkan semua transaksi penerimaan yang dicatat pada hari yang dipilih (Gambar 17), sedangkan di laporan bulanan Bendahara dapat memilih tanggal mulai dan akhir untuk laporan penerimaan. Laporan bulanan biasanya digunakan oleh Bendahara untuk mengetahui berapa jumlah penerimaan per bulannya agar dapat mengetahui berapa jumlah yang harus ditransfer ke KJB (Gambar 18). 


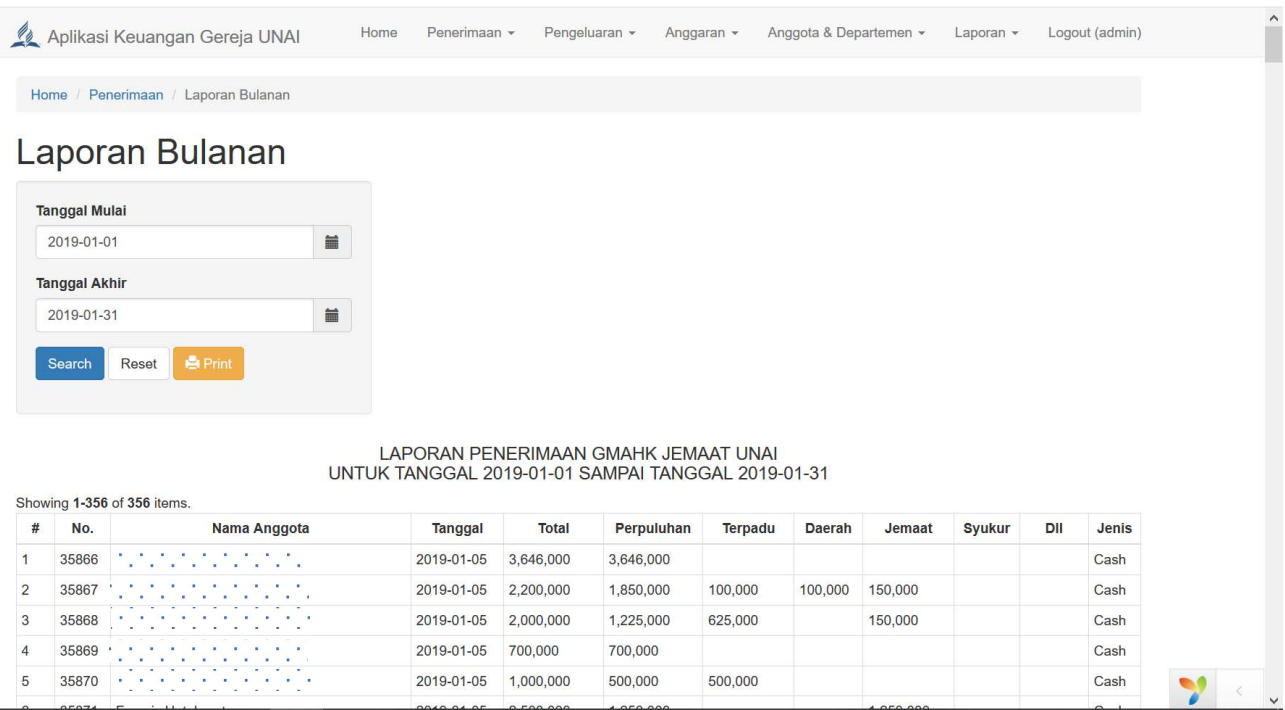

Gambar 17 Tampilan Laporan Penerimaan Bulanan
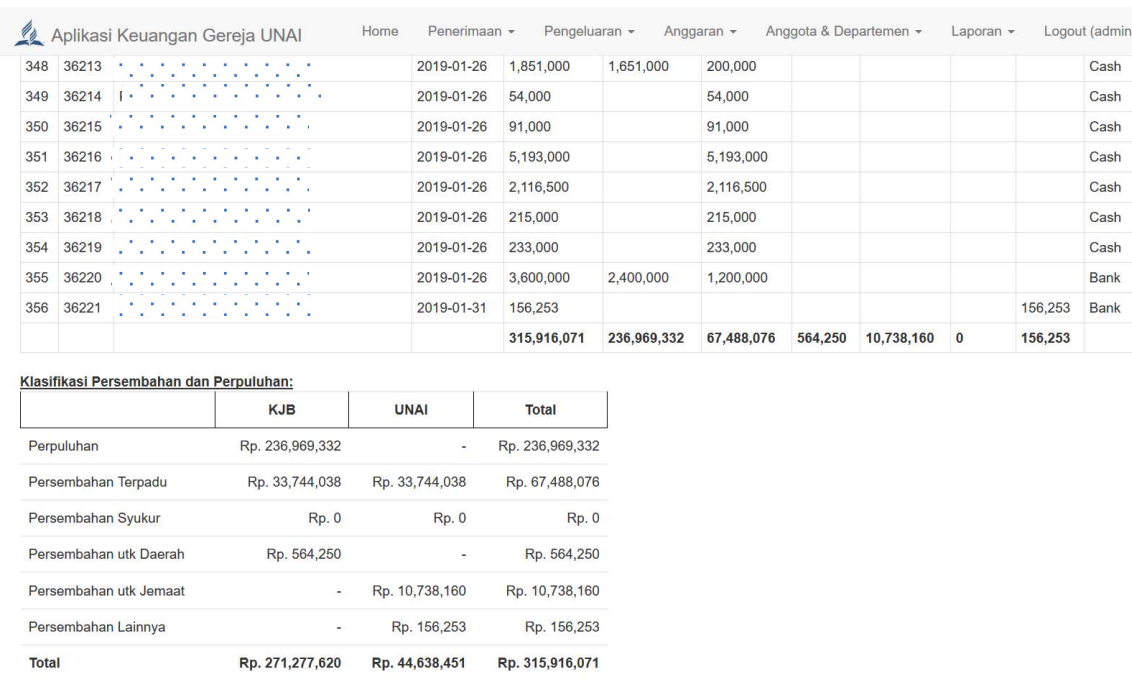

Gambar 18 Tampilan Laporan Penerimaan - Bagian Ringkasan

\section{Tampilan Laporan Anggaran}

Fungsi laporan yang digunakan dalam melakukan pengawasan terhadap penggunaan anggaran dapat diakses melalui menu Laporan dan kemudian mengklik Laporan Anggaran. Di dalam laporan anggaran (Gambar 19) terdapat informasi nominal anggaran untuk masing-masing departemen, jumlah pengeluaran, jumlah cash advance, sisa anggaran dan juga persentase penggunaan anggaran. 


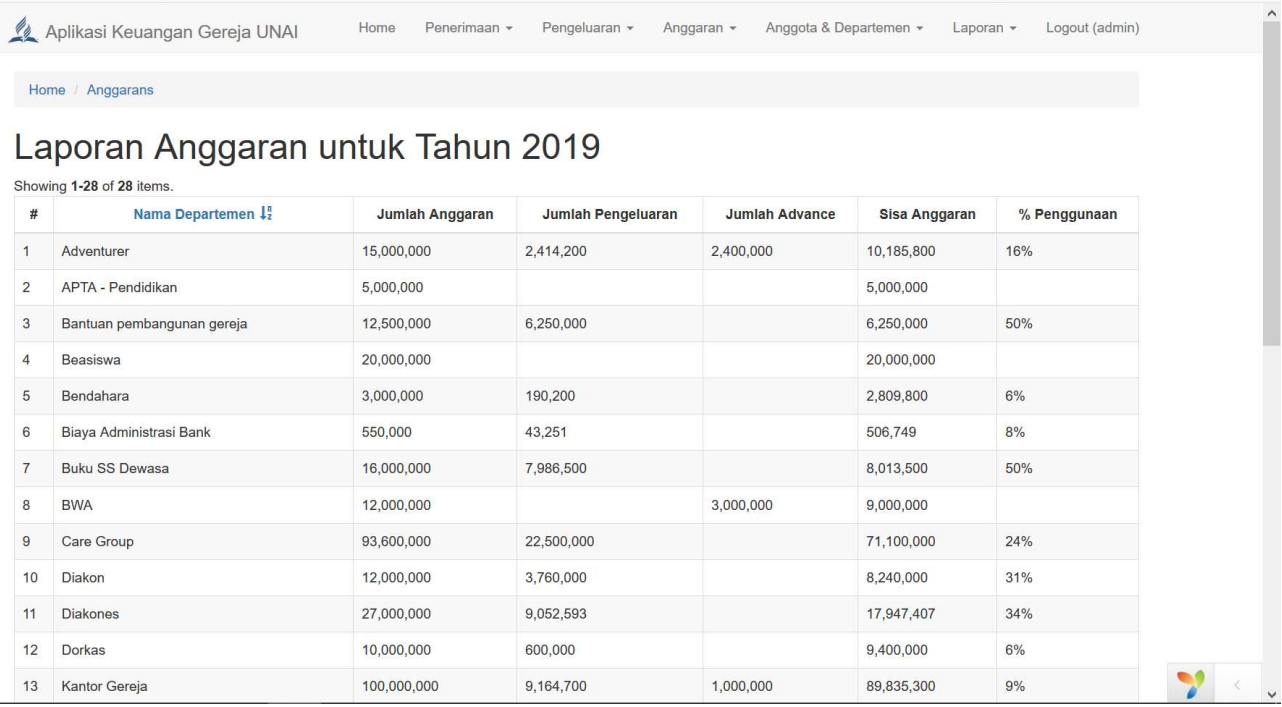

Gambar 19 Tampilan Laporan Anggaran

\section{Tampilan Laporan Pengeluaran Keseluruhan}

Gambar 19 menunjukkan laporan pengeluaran keseluruhan digunakan untuk menampilkan catatan pengeluaran keseluruhan yang tercatatat di aplikasi yang dapat di-print untuk diberikan kepada Pendeta dan Ketua Jemaat yang membidangi keuangan gereja.

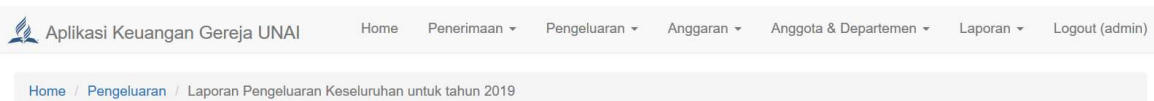

Laporan Pengeluaran Keseluruhan untuk tahun 2019

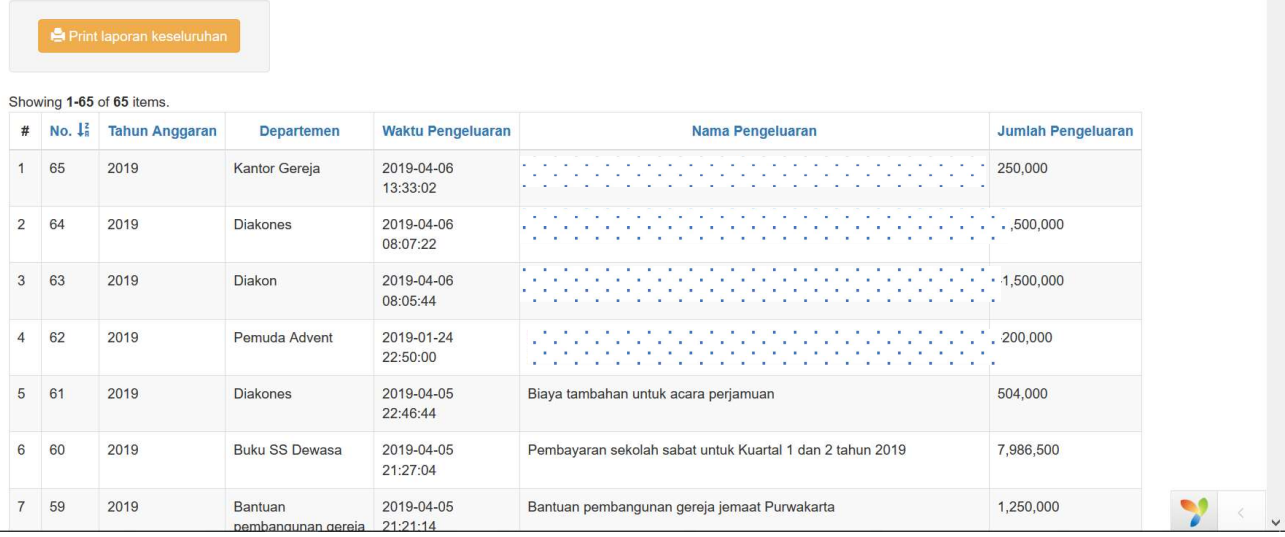

Gambar 20 Tampilan Laporan Pengeluaran

\section{Tampilan Laporan Gabungan Penerimaan dan Pengeluaran}

Gambar 21 dan 22 menampilkan laporan gabungan penerimaan dan pengeluaran jemaat. Laporan ini digunakan untuk mengetahui saldo akhir yang berasal dari perhitungan saldo awal ditambah penerimaan dikurangi pengeluaran dan cash advance. Dengan menggunakan laporan ini maka Bendahara jemaat dapat memilih tanggal mulai dan tanggal akhir laporan sehingga data yang ditampilkan akan menyesuaikan dengan tanggal yang dipilih. Laporan ini dapat digunakan oleh Bendahara jemaat pada saat melaporkan kondisi keuangan jemaat pada saat rapat majelis jemaat. 
16 Aplikasi Keuangan Gereja UNAI Home Penerimaan - Pengeluaran - Anggaran * Anggota \& Departemen - Laporan - Logout (admin)

Home / Laporan Laporan Penerimaan dan Pengeluaran tahun 2019

Laporan Penerimaan dan Pengeluaran tahun 2019

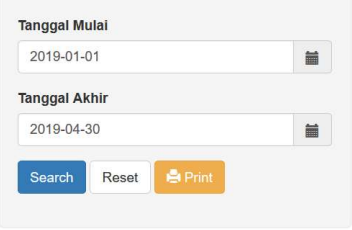

Laporan Penerimaan dan Pengeluaran GMAHK Jemaat UNAI dari January 1, 2019 sampai April 30, 2019

SALDO AWAL

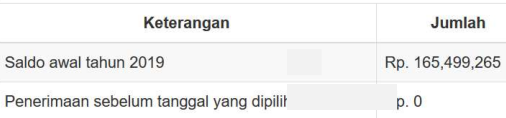

Gambar 21 Tampilan Laporan Gabungan Penerimaan dan Pengeluaran

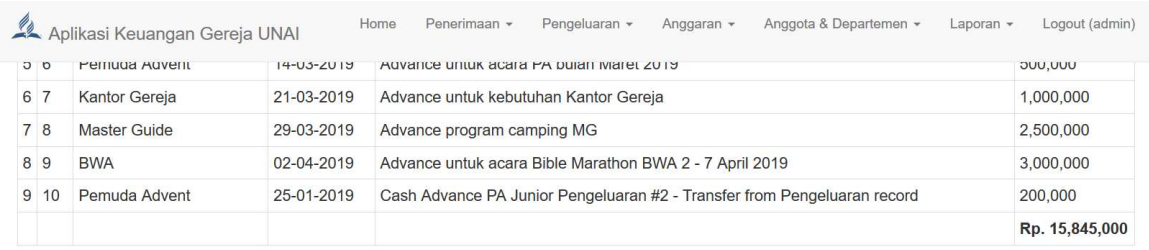

Ringkasan Penerimaan dan Pengeluaran dari January 1, 2019 sampai April 30, 2019

\begin{tabular}{|l|l|}
\hline \multicolumn{1}{|c|}{ Jenis } & \multicolumn{1}{c}{ Jumlah } \\
\hline Saldo awal sebelumnya & Rp. $165,499,265$ \\
\hline Penerimaan & Rp. $140,798,076$ \\
\hline Pengeluaran & Rp. $70,974,642$ \\
\hline Cash advance & Rp. $15,845,000$ \\
\hline Balance akhir & Rp. $\mathbf{2 1 9 , 4 7 7 , 7 0 0}$ \\
\hline
\end{tabular}

Gambar 22 Tampilan Laporan Gabungan Penerimaan dan Pengeluaran - Bagian Ringkasan

\section{Kesimpulan dan Saran}

Pada penelitian ini dilakukan perancangan dan implementasi aplikasi keuangan berdasarkan kebutuhan dari jemaat UNAI. Metode prototyping digunakan karena dalam masa pengembangan, aplikasi ini harus dapat langsung digunakan untuk memenuhi kebutuhan pencatatan transaksi keuangan yang ada. Hasil prototype diperbaharui secara bertahap sesuai dengan masukan dari pengguna sampai aplikasi dapat diimplementasikan dengan baik. Aplikasi keuangan ini menyediakan fungsi pencatatan anggota, departemen, tahun anggaran, anggaran, penerimaan, pengeluaran, cash advance dan berbagai fungsi laporan seperti: laporan anggota, laporan departemen, laporan penerimaan harian, laporan penerimaan bulanan, laporan pengeluaran, laporan anggaran, laporan gabungan penerimaan dan pengeluaran. Untuk pengembangan berikutnya diharapkan bahwa aplikasi akan ditambahkan fungsi di mana masing-masing anggota dan ketua departemen dapat melihat catatan keuangan masing-masing dengan menggunakan login yang terpisah. 


\section{Referensi}

[1] Adventist Beliefs, Internet: https://www.adventist.org/en/beliefs/living/stewardship/. Accessed: [7 April 2019].

[2] Pressman, R.S., 2010, Software Engineering: A Practitioner's Approach 7th Edition, McGraw-Hill, New York.

[3] Gereja Masehi Advent Hari Ketujuh, Buku Peraturan Jemaat Gereja Masehi Advent Hari Ketujuh, Edisi ke-18, Bandung: Indonesia Publishing House, 2010.

[4] YiiFramework, Internet: https://www.yiiframework.com.

[5] Pressman. R.S., Software Engineering: A Practicioner's Approach 7 th Edition, New York : McGraw-Hill, 2010.

[6] R. V. Palit, Y. D. Y. Rindengan, and A. S. M. Lumenta, "Rancangan Sistem Informasi Keuangan Gereja Berbasis Web Di Jemaat GMIM Bukit Moria Malalayang," Jurnal Teknik Elektro dan Komputer, vol. 4, no. 7, pp. 1-7, Dec. 2015.

[7] M. Kabuhung, "Sistem Informasi Akuntansi Penerimaan dan Pengeluaran kas Untuk Perencanaan dan Pengendalian Keuangan Pada Organisasi Nirklaba Keagamaan," Jurnal EMBA: Jurnal Riset Ekonomi, Manajemen, Bisnis dan Akuntansi, vol. 1, no. 3, May 2013. 